\title{
Bilateral total Descemet's membrane detachments after strangulation
}

This article was published in the following Dove Press journal:

Clinical Ophthalmology

27 August 2011

Number of times this article has been viewed

\section{Majid Moshirfar' \\ Brent S Betts ${ }^{2}$ \\ Maylon Hsu' \\ Huck A Holz \\ Wade McEntire}

'University of Utah, John A Moran Eye Center, Department of Ophthalmology and Visual Sciences, Salt Lake City, UT, USA; ${ }^{2}$ Temple University School of Medicine, Philadelphia, PA, USA; ${ }^{3}$ Kaiser

Permanente, Santa Clara Homestead, Santa Clara, CA, USA
Correspondence: Majid Moshirfar John A Moran Eye Center, 65 Mario Capecchi Drive, Salt Lake City, UT 84132 , USA

Tel +l 80I 5873020

Fax +18019479286

Email majid.moshirfar@hsc.utah.edu
Abstract: The eyes of a 25-year-old male were collected by the Utah Lions Eye Bank after his suicide by hanging. Following dissection of the corneoscleral buttons from intact globes, bilateral detached Descemet's membranes with subsequent scrolling in the periphery were observed. We believe these findings were caused by a large increase in intraocular pressure secondary to the hanging. Lens and anterior capsule fractures after hanging have been reported, but corneal damage has never been discussed. We invite transplant surgeons and eye bank recovery specialists to share their experience of similar corneal changes in donated eyes following strangulation or hanging.

Keywords: strangulation, hanging, suicide, Descemet's membrane, eye bank, intraocular pressure

\section{Report}

The Utah Lions Eye Bank has harvested 159 eyes from strangulations or hangings since 2003. Of these, 18 eyes (11\%) were not suitable for surgery, with 13 eyes being excluded during the screening process. The reasons for exclusion included hepatitis B positivity, human T lymphotrophic virus positivity, high risk of Creutzfeldt-Jakob disease, low endothelial cell count, or time spent incarcerated. Three eyes were noted to have focal infiltrates in the tissue. The final two eyes belonged to a 25 -year-old male who was found hanging and unresponsive. He was pronounced dead at the scene. His past medical history was significant for depression, previous suicide attempts, peritonitis, and an appendectomy, with an unremarkable past ocular history.

Following dissection of the corneoscleral buttons by the Utah Lions Eye Bank, total detachment of Descemet's membrane was seen in both corneas (Figure 1). The corneas were deemed unsuitable for transplant surgery, and the tissue was sent to another eye bank for use in keratolimbal allografts. The donor's corneoscleral buttons were retrieved by a skilled tissue recovery specialist with many years of experience. Iatrogenic trauma during tissue retrieval cannot be ruled out since corneas of intact globes are not routinely examined prior to removal. However, this is unlikely to cause such dramatic findings of complete Descemet's membrane detachments bilaterally. Histology was not available for this case.

To our knowledge, this is the first reported case of extensive Descemet's membrane detachment following a hanging. Anterior segment findings following hanging have been observed in two reports. In 1866, Dyer observed the hanging of a prisoner and reported a post mortem fracture through the crystalline lens and anterior lens capsule 


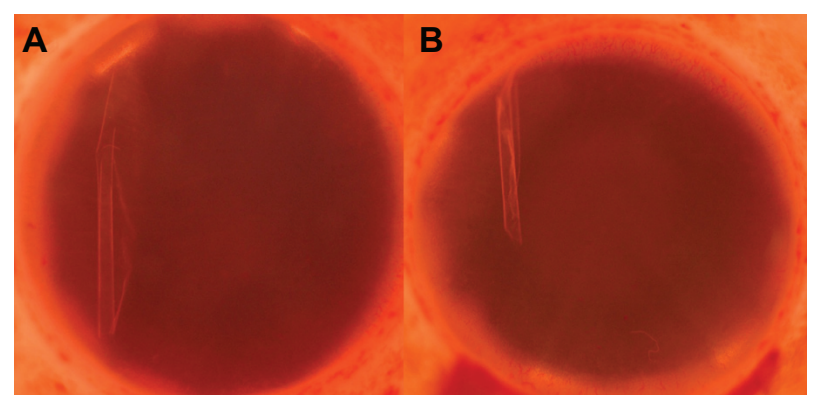

Figure I Photos of the left (A) and right (B) corneas in Optisol GS medium, showing detached, scrolled Descemet's membrane in the periphery.

in the prisoner's right eye. He reproduced these findings by hanging three dogs, with two of six eyes showing similar damage following death. ${ }^{1}$ In 1869 he saw five more hangings, and found crystalline lens and anterior capsule fractures in three of 10 eyes. $^{2}$

We speculate that a dramatic rise in intraocular pressure during hanging may stretch the cornea and cause rupture of Descemet's membrane. Tears in Descemet's membrane may occur in congenital glaucoma when the intraocular pressure increases, causing an elongation in axial length and subsequent stretching of the cornea. ${ }^{3}$ Recent research has examined how forces applied to the head influence intraocular pressure. Bakaran et al measured intraocular pressure in yoga practitioners during sirsasana (the headstand posture) and found mean intraocular pressure increased two-fold in patients immediately after assuming this position. ${ }^{4}$ Aykan et al found that the intraocular pressure increases significantly during Valsalva movements. ${ }^{5}$ Hanging may cause increased intraocular pressure secondary to increased venous pressure in the brain. He et al examined brain lesions caused by hanging via magnetic resonance imaging and found a venous distribution of brain damage. ${ }^{6}$ We suggest that further research on the effect of increased venous pressure and IOP on corneal tissue is needed. Furthermore, we would be interested in learning if other eye banks have observed similar corneal tissue changes following strangulation or hanging.

\section{Acknowledgment}

Funding was provided for this work by the Research to Prevent Blindness Foundation, New York, NY.

\section{Disclosures}

The authors have no financial interests in any materials or products discussed in the manuscript or any other disclosures.

\section{References}

1. Dyer E. Fracture of the lens and of the anterior capsules of both eyes from death by violent hanging. Trans Am Ophthalmol Soc. 1866;1(3):12-19.

2. Dyer E. Fracture of the crystalline lens in persons executed by hanging. Trans Am Ophthalmol Soc. 1869;1(6):72-75.

3. Henriques MJ, Vessani RM, Reis FAC, et al. Corneal thickness in congenital glaucoma. J Glaucoma. 2004;13(3):185-188.

4. Baskaran M, Raman K, Ramani KK, et al. Intraocular pressure changes and ocular biometry during sirsasana (headstand posture) in yoga practitioners. Ophthalmology. 2006;113(8):1327-1332.

5. Aykan U, Erdurmus M, Yilmaz B, Bilge AH. Intraocular pressure and ocular pulse amplitude variations during the Valsalva maneuver. Graefes Arch Clin Exp Ophthalmol. 2010;248(8):1183-1186.

6. He HJ, Goto N, Goto J, Ezure H, Takaoki E. Distributions of lesions in hanging suicide brains. Okajimas Folia Anat Jpn. 2002;78(6): $253-258$
Clinical Ophthalmology

\section{Publish your work in this journal}

Clinical Ophthalmology is an international, peer-reviewed journal covering all subspecialties within ophthalmology. Key topics include: Optometry; Visual science; Pharmacology and drug therapy in eye diseases; Basic Sciences; Primary and Secondary eye care; Patient Safety and Quality of Care Improvements. This journal is indexed on

\section{Dovepress}

PubMed Central and CAS, and is the official journal of The Society of Clinical Ophthalmology (SCO). The manuscript management system is completely online and includes a very quick and fair peer-review system, which is all easy to use. Visit http://www.dovepress.com/ testimonials.php to read real quotes from published authors. 